\title{
Development of MIP-based QCM Sensors for Determination of Hyaluronic Acid (HA)
}

\author{
Hiyalüronik Asit (HA) Tayini Iç̧in MIP Temelli QCM Sensörler \\ Geliştirilmesi
}

\author{
Research Article
}

Sibel Emir Diltemiz

Anadolu University, Faculty of Science, Chemistry Department, Eskişehir, Turkey.

\section{A B S TR AC T}

\begin{abstract}
n this study, quartz crystal microbalance (QCM) based recognition systems have been developed for the determination of hyaluronic acid (HA). For this purpose, firstly; N-methacryloyl-I-tyrosine (MAT), MAT-DGlucuronic acid (MAT-D-GA) and MAT-CU(II)-D-Glucuronic acid (MAT-CU(II)-D-GA) pre-organized monomers have been synthesized, and characterized. Then, D-glucuronic acid active sites of HA biomacromolecule have been imprinted on QCM sensor surface to create HA selective binding sites. In the last step, the binding interactions, usabilities in recognition and determination of prepared sensors have been investigated.
\end{abstract}

\section{Key Words}

Hyaluronic acid, MIP-QCM, mıp, quartz crystal microbalance, molecularly ımprinted polymers.

\section{öz}

u çalışmada, hyalüronik asit (HA) tayini için kuvarz kristal mikrobalans (QCM) temelli tanıma sistemleri geliştirilmiştir. Bu amaçla, öncelikle N-metakriloil-1-tirosin (MAT), MAT-D-Glukoronik asit (MAT-D-GA) ve MAT-Cu(II)-D-Glukorkonik asit (MAT-Cu(II)-D-GA) ön-organize monomerleri sentezlenmiş ve karakterize edilmiştir. Ardından, HA biyomakromolekülünün D-glucoronic asit aktif bölgeleri, HA molekülüne seçici bağlanma bölgeleri oluşturmak için QCM sensor yüzeyinde baskılanmıştır. Son adımda, elde edilen sensörlerin bağlanma etkileşimleri, tanımlama ve tayinde tekrar kullanılabilirlikleri incelenmiştir.

\section{Anahtar Kelimeler}

Hyalüronik asit, kuvars kristal mikroterazi, QCM-MIP, MIP, moleküler baskılı polimerler.

Article History: Received: Nov 30, 2017; Revised: Jan 23, 2018; Accepted: Feb 22, 2018; Available Online: Mar 26, 2018. DOI: $10.15671 /$ HJBC.2018.235

Correspondence to: S. Emir Diltemiz, Anadolu University, Faculty of Science, Chemistry Department, Eskişehir, Turkey. 


\section{INTRODUCTION}

yaluronic acid (HA) is a high-molecular-mass polysaccharide polymer that form by $\beta-(1,4)$ and $\beta$ - $(1,3)$ glycosidic linking of $D$-glucoronic acid and $\mathrm{N}$-Acetyl glycosamine groups. Chemically, called glycosminoglycans, its connective tissue is the only and simplest member of protein groups which not contain sulfate $[1,2]$. The general formula of $\mathrm{HA}$ is $\mathrm{C}_{14} \mathrm{H}_{20} \mathrm{NNaO}_{11}$, it can be found in different type of sodium salts that vary by source, isolation procedure and defining methods [3]. $\mathrm{HA}$ is one of the most important components of epithelia and nervous tissue and can be found in various region of human body such as synovial liquid, extracellular matrix of connective tissue, eye liquid, hyaline cartilage, joint liquids, dermis, epidermis and umbilical cord. It plays a critical role in fulfilling of rheological, physiochemical and biological functions. HA also plays an important role in tissue's hydration and moisturizing, cell's moving, differentiation and division, joint lubricity, transport of matter from tissues and is used in wound treatment. Due to these beneficial functions, HA is used in orthopedics, rheumatology, ophthalmology, dermatology and cosmetology [4-7].

When comparing with other natural and synthetic polymers, HA has much more water absorption capacity, nearly thousand times more from own weight [8] the hyaluronan synthase (HAS. This water absorption capacity helps important biological functions (eg. supplying of food, removing of residues) of cells that have not direct blood supply such as cartilage cells [9-11]. Due to its' shape and structure protection capability where injected without deformation for a long time, HA serves as the most preferable filling material. Carboxylic acid and hydroxyl groups that found in the structure of HA are the target locations for chemical modifications [5,12]. $\mathrm{HA}$ derivative biomaterials can be produced by these target locations. High bio compatibility and its' abundance in tissues' extracellular matrix made HA very popular for biomaterial frame material in tissue engineering studies $[7,13]$. Besides, HA is used as tumor markers in prostate and breast cancer diagnosis and treatment $[14,15]$. HA is also used in cosmetic industry for reducing age dependent wrinkles by using as filling material and skin care products due to its' moisturizing effect $[16,17]$. Generally, the high-performance liquid chromatography (HPLC) (direct UV and mass spectrometry detection, and indirect fluorescence detection after derivatization) based studies had been used for determination of HA in the literature [18-20]. Also capillary electrophoresis (CE), and multiangle laser light scattering combined with sizeexclusion chromatography (SEC-MALLS) methods were applied to determine of HA [21-22].

Molecular imprinting technology is a unique polymerization system to create recognition sites to target molecule [23-25]. In this method, target molecule is polymerized using monomers, which have specific binding sites to target molecule, cross-linker, which is suitable for monomer-target molecule interaction kind, and initiator. After removal of target molecule from the polymer structure, remaining cavity has specific shape and binding sites and this cavity can be interact with target molecule even in high interference media [26]. Therefore, Molecularly Imprinted Polymers (MIPs) called "artificial antibodies", have ability to bind target compound by their 3-D shape $[27,28]$. Also, MIPs are very useful to create recognition layer on the Quartz Crystal Microbalance (QCM) sensor systems $[29,30]$. The change in the mass due to binding of the target molecule to the binding sites on the QCM makes it possible to determine the analyte at the nano-gram level by correlating with the frequency. MIP based QCM studies exhibit wide potential use because of stability in extreme environmental conditions and cheap and easy synthesis [31].

In this study, a novel sensor system was developed for determination of HA level which is very important for living organisms. Nowadays; biotechnology, sensor systems based on nanotechnology platform technology, isolation and production of new biomaterials are also being studied extensively and accepted as priority areas for the country's economy. By accounting these factors, this study aims preparation of QCM crystals that have glucuronic acid memories for new generation biosensor systems which have mimic sites for recognition of HA bio molecule, determination of binding efficiency and finally HA determination from aqueous samples. The molecular imprinting of larger molecules like bio- 
molecules has shown limited success because of their large molecular size, conformational complexity and flexibility. So in this study, these disadvantages were overcome by using a short glucuronic acid that represents an exposed fragment of the target HA as a template. This imprinting method could open a new way to prepare imprinted polymers for the recognition of various kinds of unknown or unidentified biomolecules, if small parts of bio-molecules could be known.

\section{MATERIALS and METHODS}

The N,N'-Methylenebisacrylamide (N,N'-MBAA) and initiator $\left(\mathrm{Na}_{2} \mathrm{~S}_{2} \mathrm{O}_{5} / \mathrm{K}_{2} \mathrm{~S}_{2} \mathrm{O}_{8}\right)$ were purchased from Fluka AG (Buchs, Switzerland). $H A$, D-Glucuronic acid and 2-Propene-1-thiol were obtained from Aldrich (Milwaukee, WI, USA). All other chemicals and bio-chemicals were of analytical grade purity and obtained from Merck AG (Darmstadt, Germany). All glassware was extensively washed with dilute nitric acid before use. All water used in the experiments was purified using a Barnstead (Dubuque, IA) ROpure LP ${ }^{\circledR}$ reverse osmosis unit with a high flow cellulose acetate membrane (Barnstead D2731) followed by a Barnstead D3804 NANO pure $®$ organic/colloid removal and ion exchange packed-bed system. The conductivity of pure water obtained was 18 megaohmcm ${ }^{-1}$.

For the characterization of the prepared monomers, "JASCO FTIR 300E" spectrometer was used for FTIR analysis. $\mathrm{pH}$ measurements were made by WTW Series InoLab pH730 model pHmeter and AFM images were acquired by Q-Scope 250, Quesant Instruments, CA, USA. Binding events were followed using a Research Quartz Crystal Microbalance (RQCM) with phaselock oscillator, Kynar crystal holder, 100 $\mu \mathrm{L}$ cell volume flow cell, and 1 -in., Ti/Au, ATcut, $5-\mathrm{MHz}$ quartz crystals (all purchased from Maxtek, Inc). The RQCM phase-lock oscillator was provided loading resistance measurements and allowed for the examination of crystal damping resistance during frequency measurements. All measurements were recorded at room temperature. Sensitivity was $56.6 \mathrm{~Hz} \mathrm{~cm}^{2} \mu \mathrm{g}^{-1}$ for a $5-\mathrm{MHz}$ crystal. The AFM images of the QCM electrodes, standard silicon cantilevers (Quesant) with a force constant $\sim 40 \mathrm{~N} / \mathrm{m}$, resonant frequency $\sim 137 \mathrm{kHz}$, and radius of curvature $<10$ $\mathrm{nm}$ were used. Topography and phase images were simultaneously collected at a scan rate of 2 $\mathrm{Hz}$ under ambient laboratory conditions.

\section{Synthesis of N-Methacryloyl-L-Tyrosine Methyl Ester Monomer}

For the synthesis [32] of N-methacryloyll-tyrosine methyl ester monomer, firstly, methacryloyl benzotriazole (MA-Bt) compound was synthesized. Then, L-Tyrosine $(2 \mathrm{~g}, 11 \mathrm{mmol})$ was dissolved in $1 \mathrm{M} \mathrm{NaOH}$ aqueous solution and the MA-Bt solution in 1,4-dioxane was added slowly into this solution at room temperature. The reaction mixture was stirred at room temperature for $10 \mathrm{~min}$. (the reaction was controlled under UV light in a 1/2 EtOAc/Hexane mixture by thin layer chromatography), extracted with EtOAc $(3 \times 50$ $\mathrm{mL}$ ) and the collected water phase was acidified with a $10 \% \mathrm{HCl}$ solution to $\mathrm{pH}=6-7$. The water phase was evaporated in a rotary evaporator to give 3-(4-hydroxyphenyl)-2-[(2-methacryloyl) amino] propanoic acid (MAT) as a white solid (2.46 g, 90\% yield).

\section{Synthesis of Methacryloyltyrosine-D- Glucuronic Acid (MAT-D-GA) Pre-organized Momomer}

Methacrylamidotyrosine-D-glucuronic acid monomer [MAT-D-GA] was synthesized by the interaction of methacrylamidotyrosine (MAT), $0.1 \mathrm{mmol}$ monomer and D-glucuronic acid (DGA), $0.1 \mathrm{mmol}$ compounds (Figure 1) dissolving in dimethylsulfoxide. And then, MAT-D-GA monomer was purified by crystallization with ethanol/ethyl acetate.

\section{Pre-organization of Methacryloyltyrosine- $\mathrm{Cu}(\mathrm{II})-\mathrm{D}-\mathrm{Glucuronic}$ Acid [MAT-Cu-D-GA] Metal-Chelate Momomer}

For the synthesis of Methacryloyltyrosine-Cu(II)D-Glucuronic Acid [MAT-Cu(II)-D-GA] metalchelate monomer (Figure 2), firstly, MAT-Cu(II) monomer system was prepared. For this purpose, MAT $(0.1 \mathrm{mmol})$ and copper nitrate $\left[\mathrm{Cu}\left(\mathrm{NO}_{3}\right)_{2} \cdot 9 \mathrm{H}_{2} \mathrm{O}\right]$ $(0.1 \mathrm{mmol})$ were dissolved in dimethylsulfoxide, D-GA $(0.1 \mathrm{mmol})$ was added into this solution and stirred for $24 \mathrm{~h}$. And then, [MAT-Cu(II)-D-GA] monomer was purified by crystallization with ethanol/ethyl acetate. 


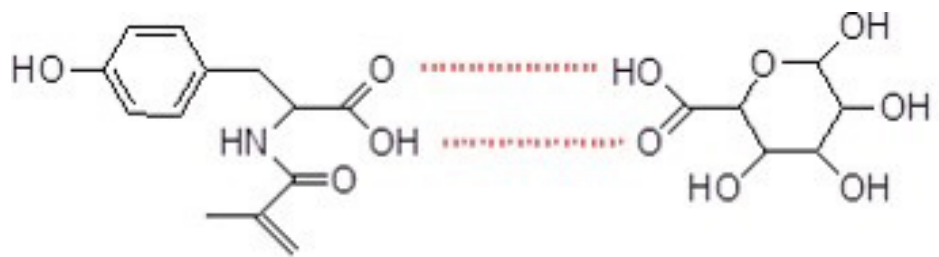

MAT

D-Glucoronic acid

Figure 1. Interaction of MAT and D-GA.

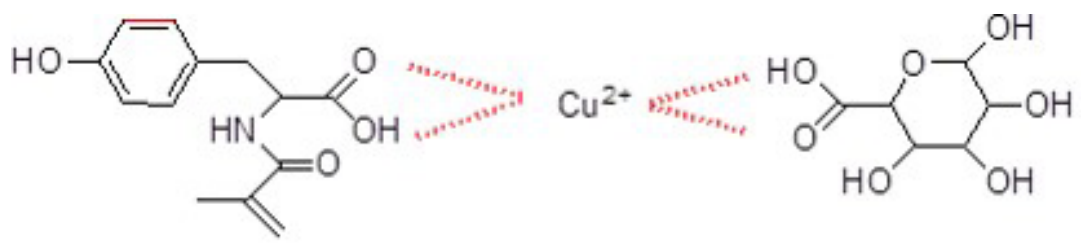

Figure 2. Structure of MAT-CU(II)-D-GA metal-chelate monomer.
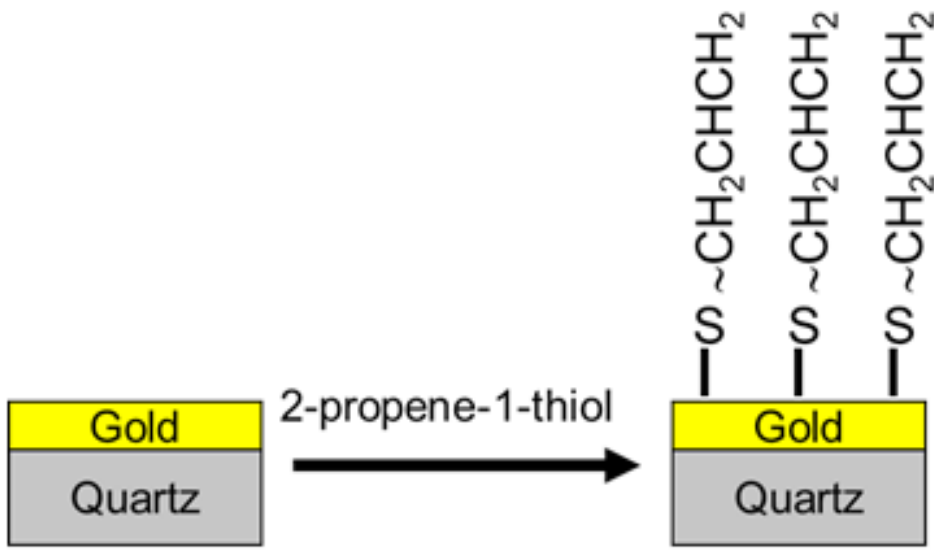

Figure 3. Activation of QCM electrodes with 2-propene-1-thiol.

\section{Activation of QCM Electrodes}

The QCM electrode surfaces were cleaned with freshly prepared piranha solution (1:3 30\% $\mathrm{H}_{2} \mathrm{O}_{2}$ /concentrated $\mathrm{H}_{2} \mathrm{SO}_{4}$ ) for 2 min, then extensively rinsed with Milli-Q water and dried with compressed air just before using. Then, the cleaned QCM electrodes were immersed into 2-propene-1-thiol ( $0.30 \mathrm{mM}$ in ethanol) for $24 \mathrm{~h}$, in order to introduce thiol groups onto gold surface of QCM electrode. Subsequently, the electrode surfaces were washed with ethanol and then deionized water, to remove excess thiol groups from the surface. Thus, a stable and homogeneous layer was formed on the gold surface (Figure 3 ).

\section{Preparation of the [MAT-D-GA] and [MAT- Cu(II)-D-GA] Imprinted QCM Electrodes}

The reaction mixture containing monomer [MATD-GA] (0.25 mmoL), crosslinking monomer (03.75
mmoL, N, N'-MBAA) and initiator $\left(\mathrm{Na}_{2} \mathrm{~S}_{2} \mathrm{O}_{5} /\right.$ $\mathrm{K}_{2} \mathrm{~S}_{2} \mathrm{O}_{8}$ ) was prepared, degassed and squeezed on allyl-activated QCM sensors. Polymerization was carried out at room temperature applying UV light irradiation for $4 \mathrm{~h}$ under nitrogen atmosphere. The control QCM electrodes that do not have D-GA memories was also prepared for comparison. QCM electrodes were washed with $0.1 \mathrm{M}$ glycine$\mathrm{HCl}$ and phosphate buffer to form D-GA memory. D-GA-imprinted polymer formation and Atomic Force Microscopy (AFM) images of this polymer were shown in Figures $4(a)$ and (b), respectively.

Preparation of MAT-Cu(II)-D-GA-imprinted QCM electrodes was carried out using the metalchelate monomer, [MA-Cu(II)-D-GA], as described in previous section. QCM electrodes were washed with $0.1 \mathrm{M}$ glycine- $\mathrm{HCl}$ and phosphate buffer to form D-GA memory. Schematic representation 

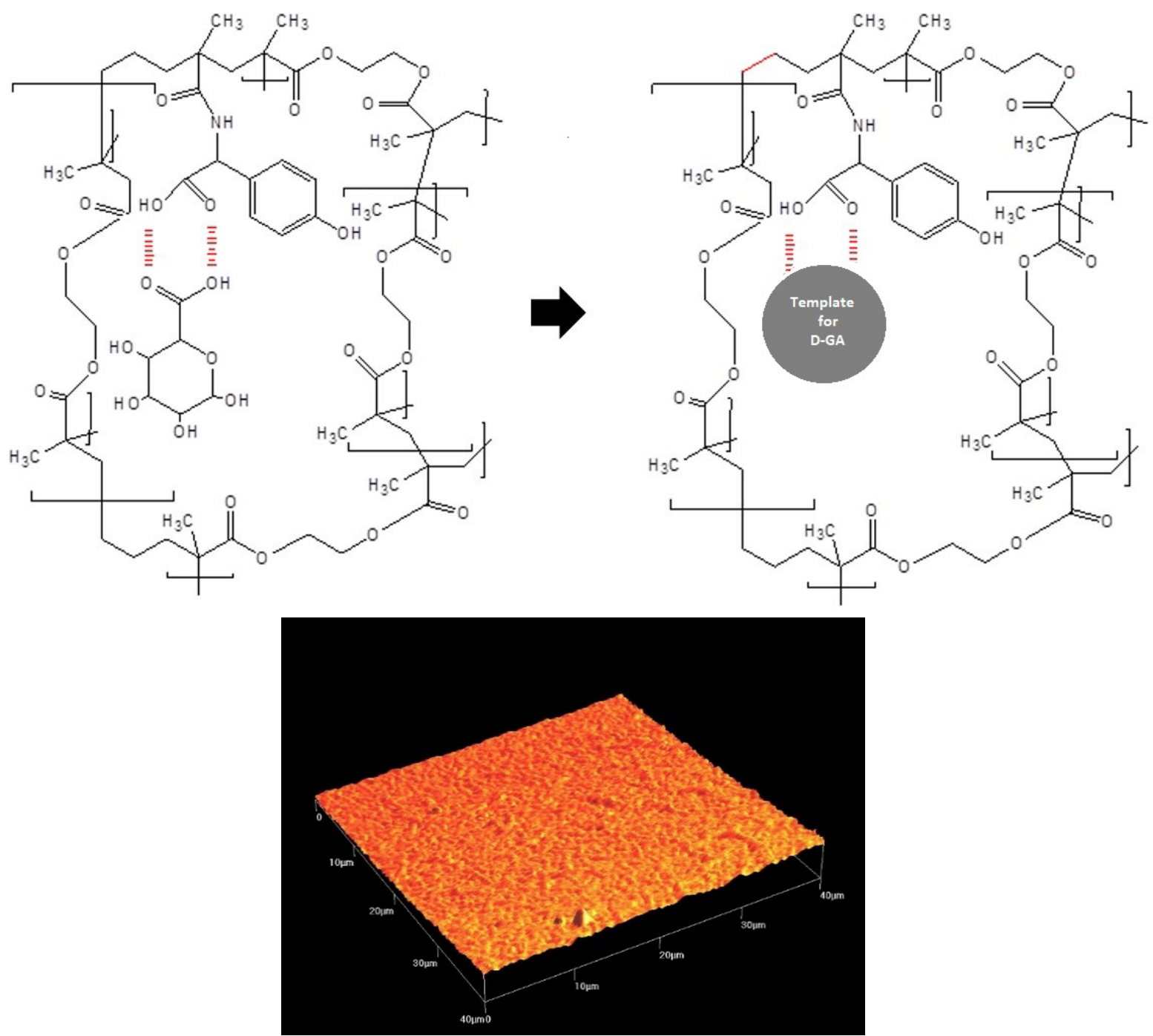

Figure 4. (a) Schematic representation of D-GA template formation on QCM sensors (b) AFM images of the [MA-D-GA] coated QCM electrode surface.

of D-GA-imprinted polymer formation and AFM images of this polymer were shown in Figures 5 (a) and (b), respectively.

\section{Evaluation of QCM-MIP Sensor Response}

The D-GA imprinted [MAT-D-GA] and [MAT-Cu(II)D-GA] coated crystals were mounted in the holder/ flow cell, rinsed with pH 7.4 HBS buffer $(10 \mathrm{mM}$ HEPES, $150 \mathrm{mM} \mathrm{NaCl}$, $3.4 \mathrm{mM}$ EDTA), and brought to resonance frequency. HA was dissolved in HBS buffer $(\mathrm{pH}$ 7.4) to have a concentration in the range of $0-250 \mathrm{mgmL}^{-1}$ and pumped through the flow cell at $0.1 \mathrm{mLmin}^{-1}$. The frequency of the sensor was monitored until it became stable. The frequency shift for each concentration of HA was determined and the evaluation was performed in triplicate. After each assay, HA was removed from the coating by washing with $0.1 \mathrm{M}$ Glycine- $\mathrm{HCl}(0.5$ $\mathrm{mlmin}^{-1}, 60 \mathrm{~min}$ ) and then, three times with HBS buffer. The frequency of the sensor approximately recovered to the value of beginning resonant frequency.

\section{RESULTS and DISCUSSION}

\section{Characterizations of Pre-Organized [MAT-D- GA] and [MAT-Cu(II)-D-GA] Monomers}

[MAT-D-GA] and [MAT-Cu(II)-D-GA] molecularly imprinted polymers were characterized with FTIR and Raman spectrometer before and after washing with $0.1 \mathrm{M}$ glycine- $\mathrm{HCl}$ buffer. The FTIR bands that were observed at $809-951 \mathrm{~cm}^{-1}$ aliphatic $-\mathrm{CH}$ stretching, $1305 \mathrm{~cm}^{-1}$ aliphatic $-\mathrm{OH}$ 

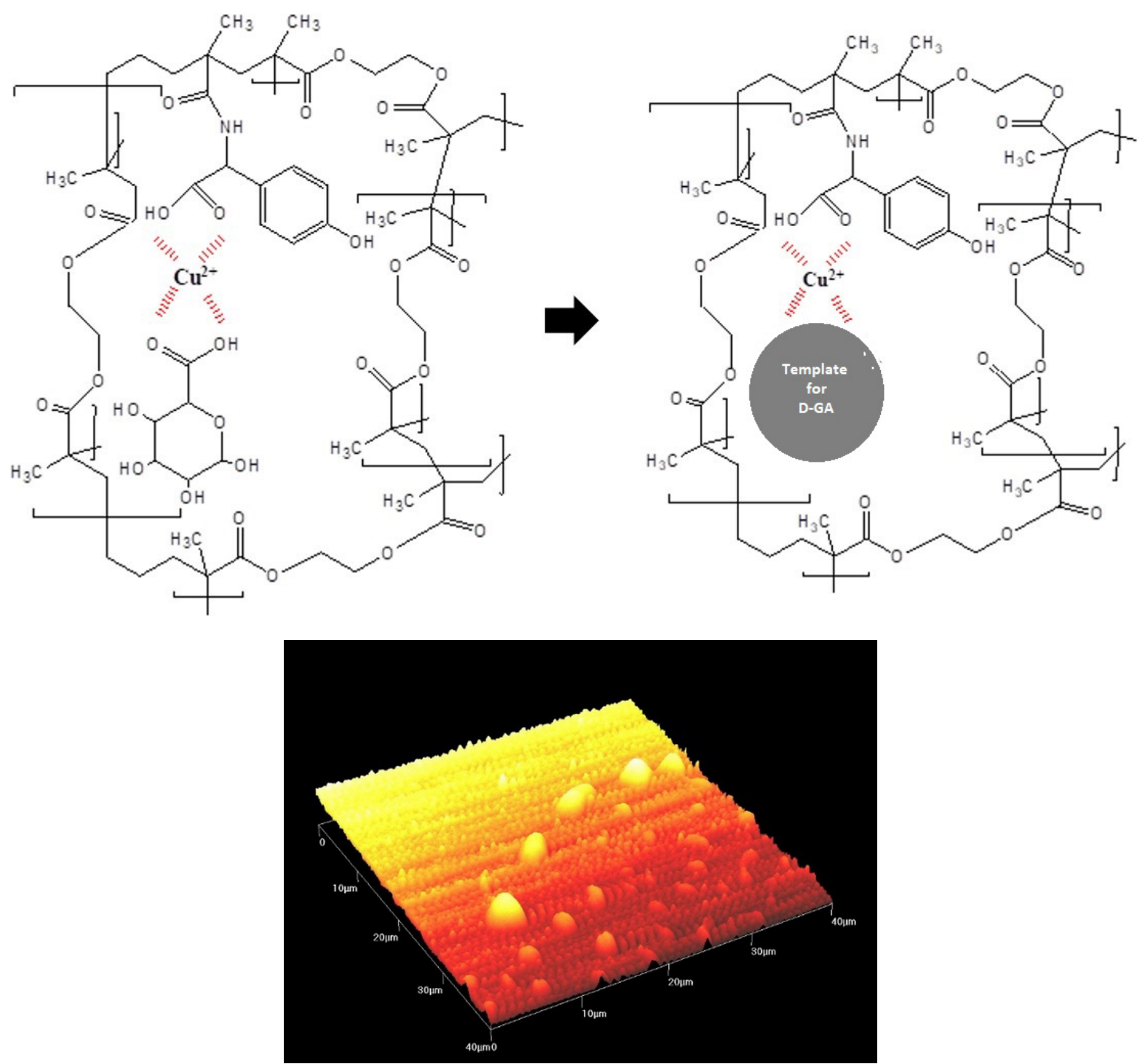

Figure 5. (a) Schematic representation of D-GA template formation on QCM sensors (b) AFM images of the [MA-CU(II)-DGA] coated QCM electrode surface.

bending. The $-\mathrm{OH}$ stretching band at $1409 \mathrm{~cm}^{-1}$ disappeared and $-\mathrm{CH}$ vibration band intensity at $3000 \mathrm{~cm}^{-1}$ decreased after removing of D-GA from the polymer structure (Figures $6 a$ and $b$ ).

As seen from Figure 7a and Figure $7 \mathrm{~b}, 809$ $951 \mathrm{~cm}^{-1}$ aliphatic $-\mathrm{CH}$ stretching, $1305 \mathrm{~cm}^{-1}$ aliphatic $-\mathrm{OH}$ bending, $1409 \mathrm{~cm}^{-1}-\mathrm{OH}$ stretching bands disappeared and $3000 \mathrm{~cm}^{-1}-\mathrm{CH}$ vibration of $D-G A$ intensity has decreased after removing of D-GA from the [MAT-Cu(II)-D-GA] structure.

\section{Sensor Assembly of [MAT-D-GA] and [MAT-Cu(II)-D-GA] Coated QCM Sensors}

We have developed a new method to form allyl based self-assembled monolayer and prepare imprinting polymer on QCM sensors. The binding of $\mathrm{HA}$ to the methacryloyl-based polymer on gold quartz crystals caused a mass change, $\Delta \mathrm{m}$, and reflection in the crystal frequency. The relationship between $\Delta \mathrm{m}$ and the frequency shift can be expressed by the Sauerbrey's equation [33].

The D-GA imprinted [MAT-D-GA] and [MAT$\mathrm{Cu}(\mathrm{II})-\mathrm{D}-\mathrm{GA}$ ] polymers are expected to bind the HA sensing. As seen in Figure 8, the frequency of the [MAT-D-GA] (Figure 8a) and [MAT-Cu(II)D-GA] (Fig 8b) coated sensor decreased after pumping the HA solution. In the $0-250 \mathrm{ppm} H A$ concentration range, the MIP coated QCM sensors showed a high frequency change for HA. These 

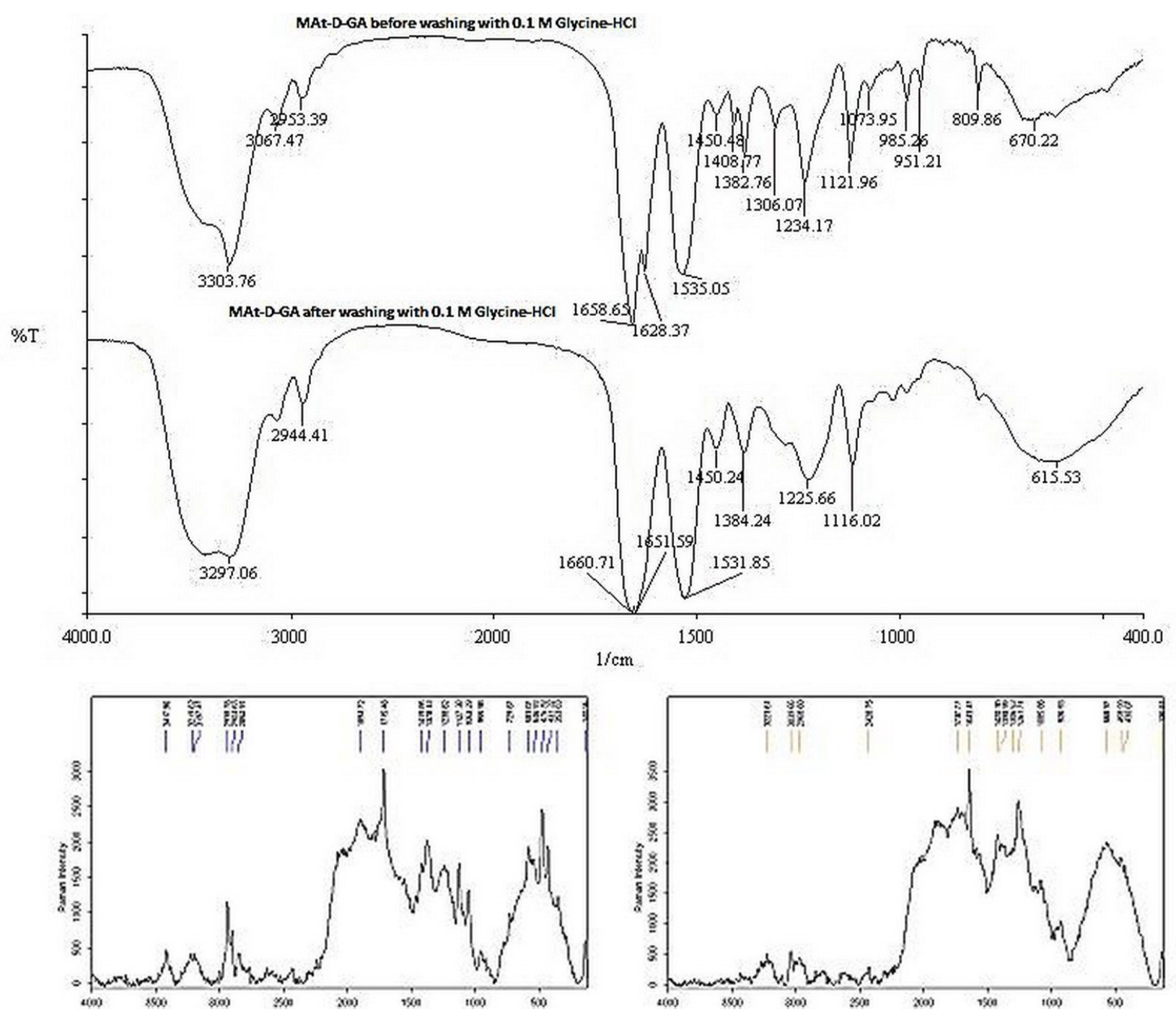

Figure 6. (a) FT-IR and (b) Raman spectra of [MAT-D-GA] polymer.

frequency changes strongly indicated that the HA molecules bound to the imprinted polymeric film on the quartz crystal via D-GA sites. Therefore, the MIP coated QCM sensors have sensitive response to $\mathrm{HA}$ due to the imprinting effect. The experiments were performed in replicates of three and the samples were analyzed in replicates of three as well.

\section{Analytical Features of QCM Based HA Imprinted Sensors}

Scatchard equilibrium isotherm model was examined to describe the interaction model between D-GA imprinted [MAT-D-GA] and [MATCU(II)-D-GA] coated QCM sensors. Scatchard equation:

$\frac{Q}{C}=\frac{Q_{\text {maks }}}{K_{D}}-\frac{Q}{K_{D}}$
In this equation;

Q : HA concentration of binding polymers

C : Free HA concentration

$Q_{\text {maks }}$ : Maximum binding site

$\mathrm{K}_{\mathrm{D}} \quad$ : Dissociation rate constant

Figure 9 and Figure 10 showed that massfrequency relationship and Scatchard graph of [MAT-D-GA] and [MAT-CU(II)-D-GA] coated QCM sensors. By the results, $K_{A}$ values were found to be 9.8 and $13.5 \mu \mathrm{M}^{-1}$ for [MAT-D-GA] and [MAT$\mathrm{CU}(\mathrm{II})-\mathrm{D}-\mathrm{GA}]$, respectively. As seen from $\mathrm{K}_{\mathrm{A}}$ values, the affinity of the binding sites is strong. This study showed that via imprinting of D-GA which is a small part of HA molecule, was carried out for the determination of HA. 


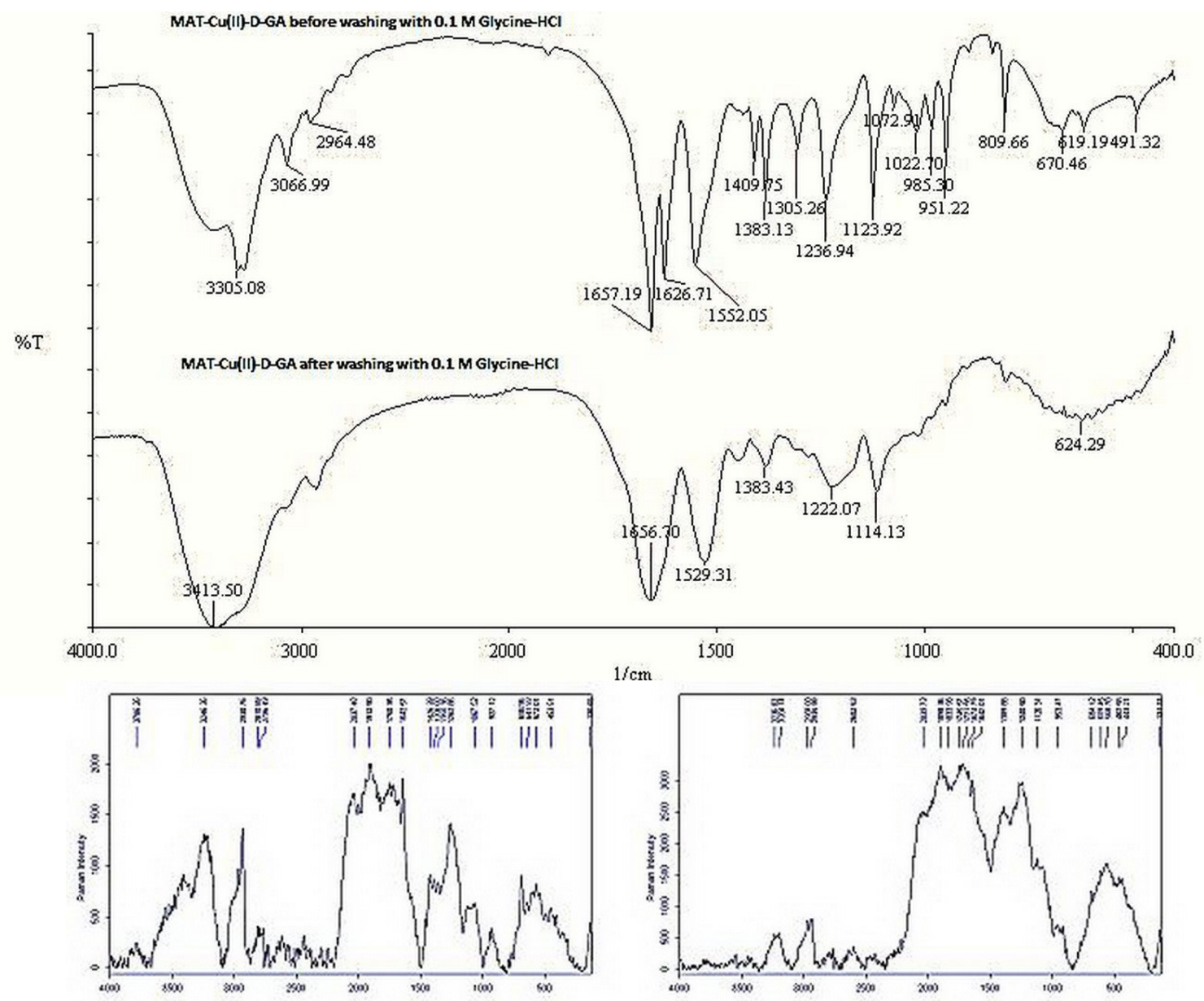

Figure 7. (a) FT-IR and (b) Raman spectra of [MAT-CU(II)-D-GA] polymer.
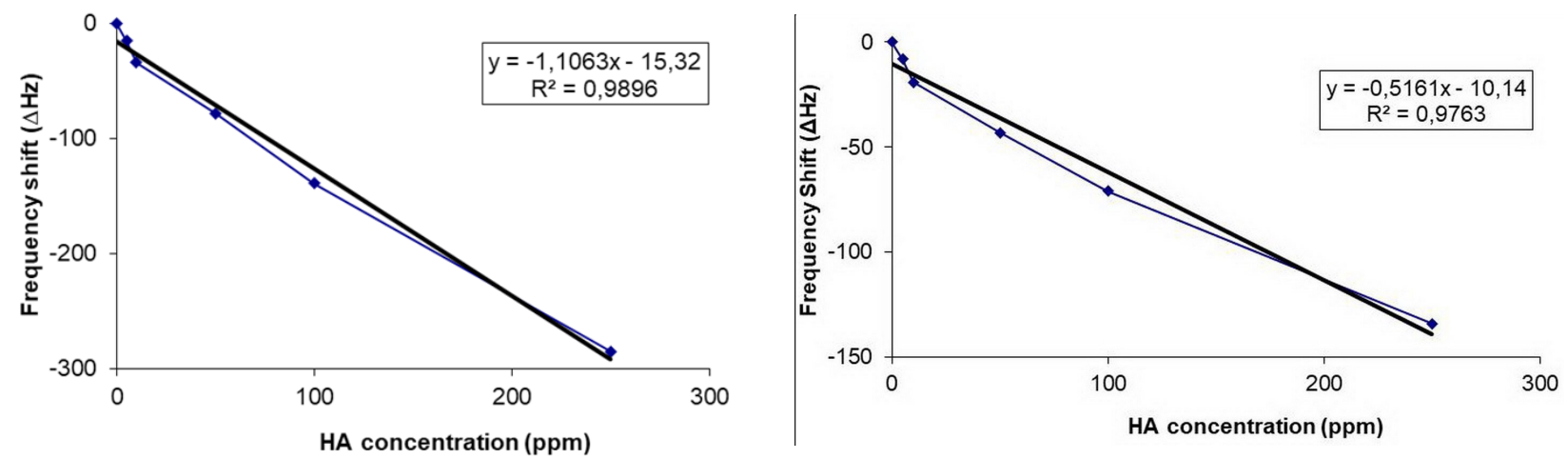

Figure 8. QCM response of (a) [MAT-D-GA] coated sensor (b) [MAT-CU(II)-D-GA] coated sensor. 

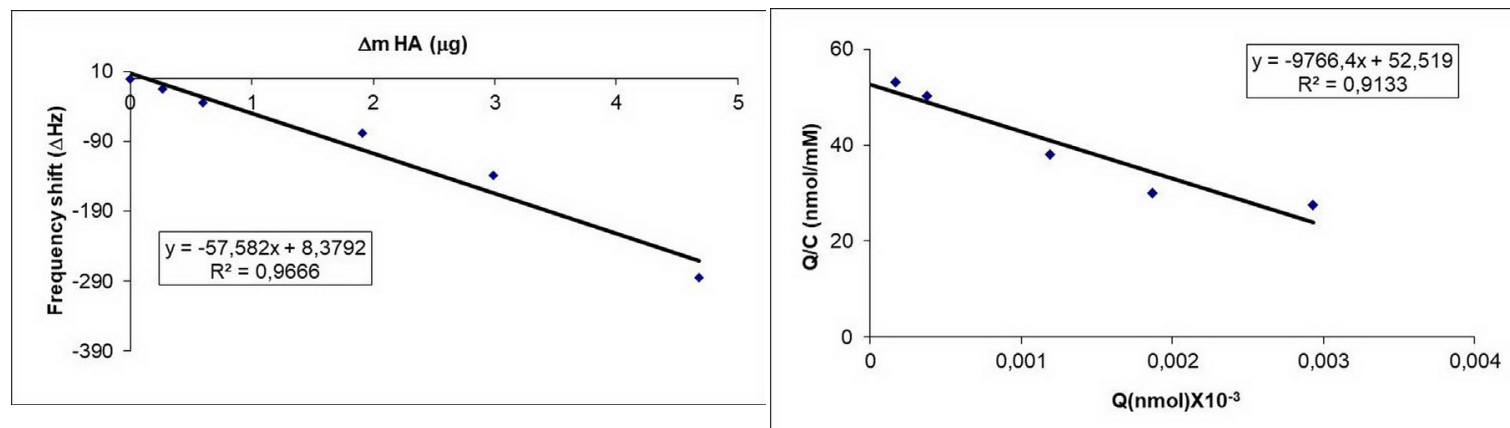

Figure 9. (a) Mass-frequency relationship of [MAT-D-GA] coated QCM sensor (b) Scatchard graph of [MAT-D-GA] coated QCM sensor.
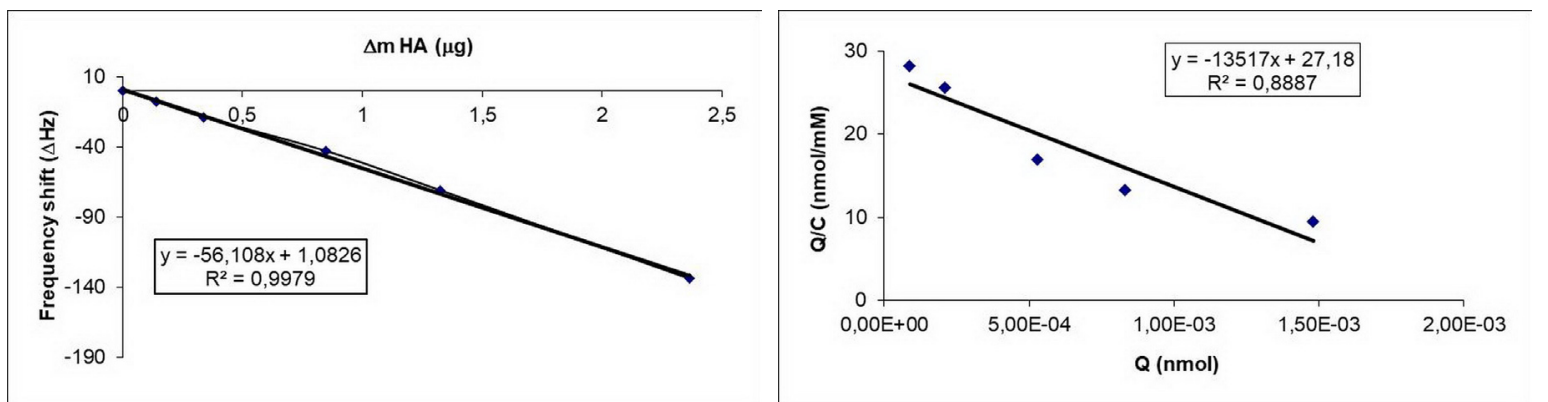

Figure 10. (a) Mass-frequency relationship of [MAT-CU(II)-D-GA] coated QCM sensor (b) Scatchard graph of [MAT-CU(II)D-GA] coated QCM sensor.

Also, two different pre-organized monomer systems were used to determine $\mathrm{HA}$ and it can be said that the system which was prepared by using $\mathrm{Cu}(\mathrm{II})$ ions monomer provided increase in selectivity due to the strong interaction between $\mathrm{Cu}(\mathrm{II})$ ions and amino acid.

\section{CONCLUSIONS}

In the work carried out, QCM-based systems which were covered with MIPs for the identification of biologically important biochemical HA were developed. Amino acids are very specific and effective ligands for metal ions and especially numerous studies on complexation of $\mathrm{Cu}(\mathrm{II})$ ions by aromatic and aliphatic amino acids indicated an increased complex stability [34-37]leading to a formation of multiple weak interactions around $\mathrm{Cu}(\mathrm{II}$. Therefore, in this study two different monomer systems, [MAT-D-GA] and [MAT-Cu(II)-D-GA], were selected and compered for the determination of $\mathrm{HA}$ molecule. For this purpose, firstly, MAT monomer and pre-organized monomers were synthesized and characterized by FT-IR and Raman methods. Then, the steps of polymerizing [MAT-D-GA] precursor monomer system and [MAT-Cu(II)-D-GA] metal chelate monomer system on 2-propene-1-thiol activated sensor surfaces under UV light were performed. The binding constants of polymer systems for HA solutions at different concentrations were determined by the measuring frequency shift for polymeric film coated sensors. As a result, $\mathrm{K}_{\mathrm{A}}$ values were determined as 9.8 and $13.5 \mu \mathrm{M}^{-1}$ for [MAT-D-GA] and [MAT-CU(II)-D-GA], respectively. These values suggested that affinity of the binding sites was very durable as well as biological receptors $\left(0.1-10 \mu \mathrm{M}^{-1}\right)$. Also, the system which was prepared using $\mathrm{Cu}(\mathrm{II})$ ions monomer provided increase in selectivity because of the strong $\mathrm{Cu}(\mathrm{II})$ ions-amino acid interactions. It can be concluded that based on our findings HA was adsorbed onto MIP-QCM sensor system by D-GA unit. Finally, the results showed that MIP-QCM designed for HA purification have high selectivity, low cost and are compatible with biological systems. 


\section{References}

1. L. Lapcík, L. Lapcík, S. De Smedt, J. Demeester P. Chabrecek, Hyaluronan: preparation, structure, properties, and applications, Chem. Rev., 98 (1998) 2663-2684.

2. J.R.E. Fraser, T.C. Laurent, U.B.G. Laurent, Hyaluronan: its nature, distribution, functions and turnover, J. Intern. Med., 242 (1997) 27-33.

3. M. Karl, The polysaccharide of the vitreous humor, J. Biol. Chem., 107 (1934) 629-634.

4. T. Luan, Y. Fang, S. Al-Assaf, G.O. Phillips, H. Zhang, Compared molecular characterization of hyaluronan using multiple-detection techniques, Polymer, 52 (2011) 5648-5658.

5. H. Yu, G. Stephanopoulos, Metabolic engineering of Escherichia coli for biosynthesis of hyaluronic acid, Metab. Eng., 10 (2008) 24-32.

6. L. Liu, Y. Liu, J. Li, G. Du, J. Chen, Microbial production of hyaluronic acid: current state, challenges, and perspectives, Microb. Cell Fact., 10 (2011) 1-9.

7. M.N. Collins, C. Birkinshaw, Hyaluronic acid based scaffolds for tissue engineering-a review, Carbohydr. Polym., 92 (2013) 1262-1279.

8. K. Kumari, P.H. Weigel, Molecular cloning, expression, and characterization of the authentic hyaluronan synthase from group C Streptococcus equisimilis., J. Biol. Chem., 272 (1997) 32539-32546.

9. Z. Cai, H. Zhang, Y. Wei, F. Cong, Hyaluronan-inorganic nanohybrid materials for biomedical applications, Biomacromolecules, 18 (2017) 1677-1696.

10. T. Luan, L. Wu, H. Zhang, Y. Wang, A study on the nature of intermolecular links in the cryotropic weak gels of hyaluronan, Carbohydr. Polym., 87 (2012) 2076-2085.

11. T. Luan, Y. Fang, S. Al-Assaf, G.O. Phillips, H. Zhang, Compared molecular characterization of hyaluronan using multiple-detection techniques, Polymer (Guildf), 52 (2011) 5648-5658.

12. C. Iavazzo, S. Athanasiou, E. Pitsouni, M.E. Falagas, Hyaluronic acid: an effective alternative treatment of interstitial cystitis, recurrent urinary tract infections, and hemorrhagic cystitis?, Eur. Urol., 51 (2007) 15341541.

13. L. Wang, H. Zhang, A. Qin, Q. Jin, B.Z. Tang, J. Ji, Theranostic hyaluronic acid prodrug micelles with aggregation-induced emission characteristics for targeted drug delivery, Sci. China Chem., 59 (2016) 1609-1615.

14. J. Hernandez, I.M. Thompson, Diagnosis and treatment of prostate cancer., Med. Clin. North Am. 88 (2004) 267-79.

15. F. Yu, F. Zhang, T. Luan, Z. Zhang, H. Zhang, Rheological studies of hyaluronan solutions based on the scaling law and constitutive models, Polymer (Guildf), 55 (2014) 295-301.

16. H. Kim, H. Jeong, S. Han, S. Beack, B.W. Hwang, M. Shin, S.S. Oh, S.K. Hahn, Hyaluronate and its derivatives for customized biomedical applications, Biomaterials, 123 (2017) 155-171.
17. L. Sherman, J. Sleeman, P. Herrlich, H. Ponta, Hyaluronate receptors: key players in growth, differentiation, migration and tumor progression, Curr. Opin. Cell Biol., 6 (1994) 726-733.

18. T. Imanari, T. Toida, I. Koshiishi, H. Toyoda, Highperformance liquid chromatographic analysis of glycosaminoglycan-derived oligosaccharides, J. Chromatogr. A, 720 (1996) 275-293.

19. A. L. Fluharty, J. A. Glick, N. M. Matusewicz, H. Kihara, High performance liquid chromatography determination of unsaturated disaccharides produced from chondroitin sulfates by chondroitinases, Biochem. Med., 27 (1982) 352-360.

20. M. E. Zebrower, F. J. Kieras, W. T. Brown, Analysis by high-performance liquid chromatography of hyaluronic acid and chondroitin sulfates, Anal. Biochem., 157 (1986) 93-99.

21. M. Kinoshita, H. Shiraishi, C. Muranushi, N. Mitsumori, T. Ando, Y. Oda, K. Kakehi, Determination of molecular mass of acidic polysaccharides by capillary electrophoresis, Biomed. Chromatogr., 16 (2002) 141145.

22. S. Hokputsa, K. Jumel, C. Alexander, S.E. Harding, A comparison of molecular mass determination of hyaluronic acid using SEC/MALLS and sedimentation equilibrium, Eur. Biophys. J. Biophys. Lett., 32 (2003), 450-456.

23. B.B. Prasad, A. Kumar, R. Singh, Molecularly imprinted polymer-based electrochemical sensor using functionalized fullerene as a nanomediator for ultratrace analysis of primaquine, Carbon, 109 (2016) 196-207.

24. E.B. Özkütük, S.E. Diltemiz, E. Özalp, R. Say, A. Ersöz, Ligand exchange based paraoxon imprinted QCM sensor, Mater. Sci. Eng. C, 33 (2013) 938-942.

25. S.E. Diltemiz, D. Hür, R. Keçili, A. Ersöz, R. Say, New synthesis method for 4-MAPBA monomer and using for the recognition of IgM and mannose with MIPbased QCM sensors, Analyst, 138 (2013) 1558-1563.

26. E. Yilmaz, D. Majidi, E. Ozgur, A. Denizli, Whole cell imprinting based Escherichia coli sensors: A study for SPR and QCM, Sens. Actuat. B Chem., 209 (2015) 714-721.

27. M. Karabörk; E. Birlik Özkütük; A. Ersöz; R. Say, Selective Preconcentration of $\mathrm{Fe}^{3+}$ Using IonImprinted Thermosensitive Particles Hacettepe J. Biol. Chem., 38 (2010) 27-39.

28. Ç. Çiçek, F. Yılmaz, E. Özgür, H. Yavuz, A. Denizli, Molecularly Imprinted Quartz Crystal Microbalance Sensor (QCM) for Bilirubin Detection, Chemosensors, 4 (2016) 1-13.

29. D. Croux, A. Weustenraed, P. Pobedinskas, F. Horemans, H. Diliën, K. Haenen, T. Cleij, P. Wagner, R. Thoelen, W. De Ceuninck, Development of multichannel quartz crystal microbalances for MIP-based biosensing, Phys. Status Solidi., 209 (2012) 892-899.

30. G. Sener, E. Ozgur, E. Yılmaz, L. Uzun, R. Say, A. Denizli, Quartz crystal microbalance based nanosensor for lysozyme detection with lysozyme imprinted nanoparticles, Biosens. Bioelectron., 26 (2010) 815821. 
31. S. Emir Diltemiz, R. Keçili, A. Ersöz, R. Say, Molecular imprinting technology in quartz crystal microbalance (QCM) sensors, Sensors (Basel), 17 (2017) 454-473.

32. D. Hur, S. Ekti, R. Say, N-acylbenzotriazole mediated synthesis of some methacrylamido amino acids, Lett. Org. Chem., 4 (2007) 585-587.

33. U. Latif, S. Can, O. Hayden, P. Grillberger, F.L. Dickert, Sauerbrey and anti-Sauerbrey behavioral studies in QCM sensors-detection of bioanalytes, Sens. Actuators B Chem., 176 (2013) 825-830.

34. W. Bal, M. Dyba, H. Kozłowski, The impact of the amino-acid sequence on the specificity of copper(II) interactions with peptides having nonco-ordinating side-chains., Acta Biochim. Pol., 44 (1997) 467-476.
35. L. Uzun, R. Uzek, S. Şenel, R. Say, A. Denizli, Chiral recognition of proteins having $L$-histidine residues on the surface with lanthanide ion complex incorporatedmolecularly imprinted fluorescent nanoparticles, Mater. Sci. Eng. C, 33 (2013) 3432-3439.

36. C.L. Gatlin, F. Ture ek, T. Vaisar, Gas-phase complexes of amino acids with $\mathrm{Cu}(\mathrm{II})$ and diimine ligands. Part I. Aliphatic and aromatic amino acids, J. Mass Spectrom., 30 (1995) 1605-1616.

37. H.A. Akdamar, N.Y. Sarıözlü, A.A. Özcan, A. Ersöz, A. Denizli, R. Say, Separation and purification of hyaluronic acid by glucuronic acid imprinted microbeads, Mater. Sci. Eng. C, 29 (2009) 1404-1408. 